\title{
On the 80th birthdays of \\ Willem J.J.O. de Wilde and Brigitta E.E. Duyfjes
}

\author{
P. Baas ${ }^{1}$, J.F. Veldkamp ${ }^{1}$, P.C. van Welzen ${ }^{1}$
}

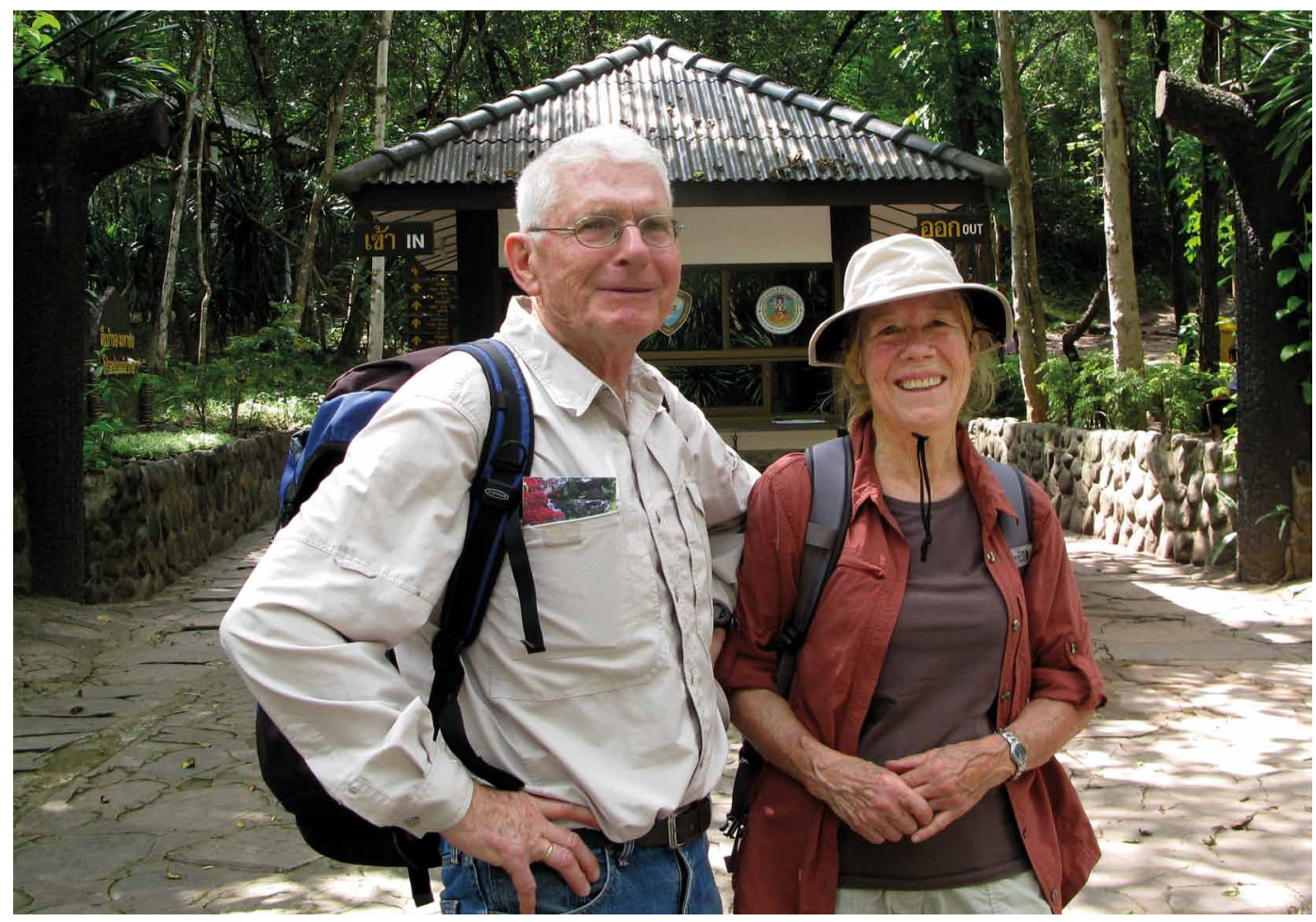

Willem and Brigitta at the entrance of Phu KraDueng National Park, Loei Prov., NE Thailand.

This year we celebrate the 80th birthdays of Brigitta de WildeDuyfjes (on 29 June) and of her husband Willem de Wilde (on 16 September). For well over 50 years they have been such a strong and productive team in taxonomic research on tropical plant families and fieldwork in the Flora Malesiana region and Thailand, that a combined laudatio seems justified, although this puts a heavy burden on us, the writers, to maintain a proper gender balance. If we fail, this is simply due to the fact that throughout most of his career Willem has been on the permanent staff of the Rijksherbarium (via many intermediate stages morphed into a research group of the Naturalis Biodiversity Center) while Brigitta was a demonstrator (teaching assistant) at the Rijksherbarium in her early student days in the sixties, but did not rejoin us until 1998 as an Honorary Staff member following a successful career as high school teacher of biology at the Rijnland Lyceum in Wassenaar.

Brigitta Duyfjes was born in Bandung, Indonesia, in 1936 and came to The Netherlands in 1946. From 1955 she studied Biology at Leiden University, completed in 1966 with a cum laude

\footnotetext{
Naturalis Biodiversity Center, section Botany, P.O. Box 9517, 2300 RA Leiden, The Netherlands;

corresponding author e-mail: pieter.baas@naturalis.nl.
}

degree. The somewhat delayed MSc degree was due to the fact that she accompanied her husband for three years in tropical Africa (see below). She subsequently joined the staff of the Laboratory for Plant Taxonomy and Geography of Wageningen University where she completed her PhD with H.C.D. de Wit on the taxonomy of the notoriously difficult genus Allium in Africa in 1977. After rejoining the Leiden Herbarium in 1998 she first completed a number of small family treatments for Flora Malesiana on Coriariaceae, Hernandiaceae, and Stemonaceae, before joining her husband in revising other families; Campanulaceae, Cucurbitaceae, Lythraceae, and Polygalaceae, for Flora Malesiana and/or related floras (see below).

Willem de Wilde, born 1936 in Heemskerk, North Holland, also studied biology at Leiden University, where he met and married Brigitta, and obtained cum laude degrees for his BSc and MSc. $\mathrm{He}$, too, was a teaching assistant at the Rijksherbarium under H.J. Lam. Following his graduation he worked for three years for the Dutch Overseas Development Agency in tropical Africa under H.C.D. de Wit and engaged in botanical exploration, teaching, and herbarium curation in Cameroon, Ethiopia, and Ivory Coast. In 1966 he was appointed on the scientific staff of the Rijksherbarium - first to monograph the genus Adenia (Passifloraceae) for his PhD in 1971 under supervision of 
C.G.G.J. van Steenis. He subsequently remained faithful to Flora Malesiana and related flora projects, and over the years completed treatments of Passifloraceae, Myristicaceae, Cucurbitaceae, Campanulaceae, Polygalaceae, and Lythraceae for Flora Malesiana with very significant spin-offs for the Flora of Thailand, the Flora of Peninsular Malaysia, and the Tree Flora of Sabah and Sarawak. Currently he works with Brigitta on a revision of Alangium. Together they published well over 600 new taxa and combinations.

Over the years Willem and Brigitta made numerous collecting trips, assembling altogether around 25000 herbarium specimens, of which over 20000 jointly and with a fair percentage as additional collectors in expedition teams in Brunei, Indonesia, Malaysia, and Thailand. Willem's earliest collections are from 1956. In 1959 he made important collections in Turkey with a group of friends and fellow students of Biology. Brigitta's first collections date from 1960, mainly from Scandinavia. Collections by De Wilde \& De Wilde-Duyfjes are always of great quality, and often represent novelties, or rediscoveries of rare and endangered species. They enriched the Naturalis collections with 161 types. Their names will remain forever linked with the natural history of the Gunung Leuser Biosphere Reserve in North Sumatra, where they collected extensively during five expeditions in 1972, 1974, 1979, 1985, and 1991 and summarised its rich but endangered flora in a number of review papers and a checklist of plant species. Other favoured destinations for plant hunting were Borneo - Bukit Raya, Brunei, and Sabah (Sepilok and Mt Kinabalu); Java; Sulawesi; and numerous localities in Thailand. For their taxonomic herbarium studies they visited most major European and SE Asian herbaria multiple times.

Wherever they go Brigitta and Willem are welcome guests, which in turn is a reflection of their own generosity in sharing knowledge and expertise, and their reciprocal hospitality towards visitors of the Leiden Herbarium. Especially students from SE Asia have been on the receiving end of their very helpful attitude whenever either domestic or botanical problems needed a solution.

The De Wildes share a passion for nature conservation worldwide and natural products grown in their own garden in the countryside of the hamlet Ofwegen - a true natural paradise. Only one weakness detracts from their Green credentials and sustainable life style: they drive a vintage Mercedes, restored by their son Hein; for short distances only, but doubtlessly wasteful on the fossil fuels. Their personalities are nicely complimentary: Brigitta always bubbles with optimism and enthusiasm, a much needed antidote for the occasional pessimism which darkens Willem's days when it comes to problems like the future of our planet or of plant systematics in the world's herbaria. That pessimism is blissfully compensated by a fine and subtle sense of humour, which makes it good fun to be around him.

We are greatly indebted to Willem and Brigitta for both their botanical and social contributions to our institute and to botany, and wish them many more happy and productive years as Honorary Staff of the Herbarium of Naturalis Biodiversiy Center.

\section{Eponymy of Willem J.J.O. De Wilde \& Brigitta E.E. Duyfjes}

Agalmyla wildeorum Hilliard \& B.L.Burtt, Edinburgh J. Bot. 59 (2002) 61. Gesneriaceae.

Anoectochilus dewildeorum Ormerod, Taiwania 50 (2005) 2. Orchidaceae.

Ardisia dewildei C.M.Hu, Blumea 47 (2002) 499. Primulaceae. Baphia dewildeana Soladoye, Kew Bull. 37 (1982) 297.

Fabaceae.

Bulbophyllum dewildei J.J.Verm., Blumea 41 (1996) 364.

Orchidaceae.

Crepidium dewildeanum Szlach. \& Marg., Fragm. Florist. Geobot. 43 (1998) 184. Orchidaceae.

Cyperus dewildeorum (J.Raynal) Lye, Nordic J. Bot. 3 (1983) 231. Cyperaceae.

Dendrochilum dewildeorum J.J.Wood \& J.B.Comber, Lindleyana 10 (1995) 59 ('dewildei'). Orchidaceae.

Dichapetalum dewildei Breteler, Meded. Landbouwhoogeschool Wageningen 78 (1978) 56. Dichapetalaceae.

Didissandra wildeana A.Weber \& B.L.Burtt, Beitr. Biol. Pflanzen 70 (1997, publ. 1998) 218. Gesneriaceae.

Drypetes dewildei Airy Shaw, Kew Bull. 32 (1978) 380.

Putranjivaceae.

Elaeocarpus brigittae Coode, Kew Bull. 49 (1994) 237.

Elaeocarpaceae.

Elaeocarpus dewildei Weibel, Candollea 35 (1980) 514.

Elaeocarpaceae.

Freycinetia dewildeorum Pasaribu, Reinwardtia 13 (2010) 147. Pandanaceae.

Goniothalamus dewildei R.M.K.Saunders, Bot. J. Linn. Soc. 139 (2002) 241. Annonaceae.

Isachne fera Veldk., Blumea, ined. Poaceae.

Mangifera dewildei Kosterm. in Kosterm. \& J.Bompard, Mangoes (1993) 83. Anacardiaceae.

Monophyllaea wildeana B.L.Burtt, Notes Roy. Bot. Gard. Edinburgh 37 (1978) 57. Gesneriaceae.

Phyllanthus dewildeanus Jean F.Brunel, Gen. Phyllanthus Afr. Intertrop. Madag. (1987) 398. Phyllanthaceae.

Phyllanthus dewildeorum M.G.Gilbert, Kew Bull. 42 (1987) 356 ('dewildiorum'). Phyllanthaceae.

Pycreus dewildeorum J. Raynal, Kew Bull. 23 (1969) 313. Cyperaceae.

Sarcotheca laxa (Ridl.) R.Knuth var. brigittae Veldk., Blumea 38 (1994) 459. Oxalidaceae.

Senecio dewildeorum Tjitr., Reinwardtia 12 (2002) 126.

Asteraceae.

Symplocos columbulae Noot., Blumea 26 (1980) 416 ('columbuli'). Symplocaceae.

Xanthophyllum brigittae Meijden, FI. Males. ser. 1, 10 (1988) 511. Polygalaceae. 